Doi: 10.4274/vhd.2018.1.0001

Viral Hepatitis Journal 2018;24(1):1-2

\title{
Epidemiology of Viral Hepatitis Changes in Our Country
} Ülkemizde Viral Hepatitlerin Epidemiyolojisi Değișiyor

\author{
๑ Nurcan BAYKAM1ㄴ ๑ Rahmet GÜNER² \\ ${ }^{1}$ Hitit University Faculty of Medicine, Department of Infectious Diseases and Clinical Microbiology, Çorum, Turkey \\ ${ }^{2}$ Ankara Yıldırım Beyazıt University Faculty of Medicine, Department of Infectious Diseases and Clinical Microbiology, Ankara, Turkey
}

The most important interventions in our country that significantly affect the epidemiology of viral hepatitis are the introduction of hepatitis $B$ vaccine into the routine vaccination program for newborns since 1998 and the introduction of catch up vaccination strategies and screening for high-risk groups. In addition, the development of our surveillance system, the introduction of hepatitis $A$ vaccine into the routine vaccination program, and the addition of studying nucleic acid testing to serological screening in blood donors are other important interventions.

When the data of the Ministry of Health for the period including 2009-2017 is reviewed, it is remarkable that there is a decrease in the cases of acute hepatitis $A$ and this decrease is observed in all regions (1). For hepatitis $B$, the hepatitis B surface antigen (HBsAg) positivity varies between $3.4 \%$ and $7.8 \%$ according to the results of the field study conducted by the Viral Hepatitis Society, while it is $4 \%$ on the field study of the Turkish Liver Research Society $(2,3)$. In addition, the fact that one out of every three people over 18 years old in our country has been exposed to hepatitis B virus (HBV), having more than 2 million HBsAg positive in the adult age group and having only $12 \%$ of these people being aware of their situation is the striking result of this study (3). A modeling study of Toy et al. (4), including 339 articles from 1999 to 2009, provided data on age-specific and region-specific hepatitis B prevalence in our country, healthcarerelated groups such as blood donors and military units, pregnant women and health personnel, and high-risk groups. According to the results of this study, age and regional differences in our country are predominant and the prevalence of hepatitis $B$ is $4.57 \%$. This ratio numerically indicates the fact that about 3.3 million people are infected with HBV and about 330.000 cases of chronic hepatitis B are present. $70 \%$ of these cases are hepatitis
B e antigen negative and 99\% genotype D. Pregnant women had a predominantly $1.7 \%$ HBsAg positivity.

Şahin et al. (5) reported HBsAg positivity as $1 \%$ in pregnant women in Şırnak and Cizre cities in their study currently published in this issue of Viral Hepatitis Journal. In another study that was conducted in our eastern cities, seroprevalence was found significantly low and another good point was having anti-HBs positivity as $54.5 \%$ for pregnants under age 19 that is higher than the group above 19 years old. This is an indication that the newborn routine hepatitis $B$ vaccination studies have reached the target.

Furuncuoğlu et al. (6) support the data of Şahin et al. (5) in the study of hepatitis B seroprevalance of 7605 pregnant women in three different periods of 1995-2015. HBsAg positivity was found to decrease from $2.6 \%$ to $0.8 \%$ between 1995 and 2001, while anti-HBs positivity increased from $9.5 \%$ to $17.5 \%$. Since prevention of vertical transmission means to prevent new hepatitis $B$ infections, it is very important to screen hepatitis B infection in pregnancy.

Studies in the prevention of hepatitis B infection in our country are pleasing and promising. However, much more action should be taken into account within the scope of the project focused on hepatitis elimination in 2030, which was initiated by the World Health Organization. Our national strategic plan, which aims to raise awareness, improve surveillance and screening, identify highrisk groups, and increase access to care, are crucial to take action.

\section{References}

1. Sağlık Bakanlığı Bulaşıcı Hastalıklar Dairesi Başkanlığı Istatistikleri. www.saglik.gov.tr

2. Balık I, Tosun S, Tabak F, Saltoğlu N, Örmeci N, Şencan I, Gürbüz Y, Öztoprak N. Ülkemizde gezici ekiple viral hepatit

Baykam N, Güner R. Epidemiology of Viral Hepatitis Changes in Our Country. Viral Hepat J. 2018;24:1-2. 
epidemiyolojisinin araştırılması (VHSD Otobüs Projesi). XI. Ulusal Viral Hepatit Kongresi. 12-15 Nisan 2012, Antalya, s 44, PS01-10

3. Tozun N, Ozdogan O, Cakaloglu Y, Idilman R, Karasu Z, Akarca U, Kaymakoglu S, Ergonul O. Seroprevalence of hepatitis B and C virus infections and risk factors in Turkey: a fieldwork TURHEP study. Clin Microbiol Infect. 2015;21:1020-1026.

4. Toy M, Onder FO, Idilman R, Kabacam G, Richardus JH, Bozdayi M, Akdogan M, Kuloglu Z, Kansu A, Schalm S, Yurdaydin C. The cost-effectiveness of treating chronic hepatitis $B$ patients in a median endemic and middle income country. Eur J Health Econ. 2012;13:663-676

5. Şahin $M$, Zencir $M$, Gözübüyük $A A$, Pektaș BA. Seroprevalence of hepatitis B surface antigen, anti-hepatitis B surface and antihepatitis C virus among pregnant women residing in Şırnak Province. Viral Hepatitis J. 2018;24:7-11.

6. Furuncuoglu $\mathrm{Y}$, Bolukbas FF, Bolukbas $\mathrm{C}$, Torun P, Ozturk R. Changes in the prevalence of HBV infection in pregnant women in Turkey between 1995 and 2015: a 20-year evaluation. Postgrad Med J. 2016;92:510-513. 